\title{
BoOKS RECEIVED/ LIVRES RÉÇUS
}

Agier, Michel. 2016. Borderlands: Towards an Anthropology of the Cosmopolitan Condition. Hoboken, N.J.: Wiley Blackwell. 208 pp., \$27.95 paper (9780745696805)

Atkinson, Will. Beyond Bourdieu. Cambridge and Malden: Polity, 2016. 175 pp., paper. \$27.95 paper (9781509507498)

Badiou, Alain. Translated by Susan Spitzer. Black: The Brilliance of a Non-Color. Cambridge and Malden: Polity, 2016. 80 pp., \$13.95 paper (978-1-5095-1208-9)

Badiou, Alain. Translated by Susan Spitzer. In Praise of Mathematics. Cambridge and Malden: Polity, 2016. 144 pp., \$54.00 hardcover (9781509512027)

Badiou, Alain. Translated by Robin Mackay. Our Wound is not so Recent: Thinking the Paris Killings of 13 November. Cambridge and Malden: Polity, 2016. 80 pp., \$17.95 hardcover (9781509514939)

Bauman, Zygmunt. Strangers at our Door. Cambridge and Malden: Polity Press, 2016. 125 pp., \$15.95 paper (9781509512171)

Blum, Alan. The Dying Body as a Lived Experience. London and New York: Routledge, 2017. 213 pp., \$160.00 hardcover (97811386555157); \$54.95 ebook (9781315622712)

Blum, Alan and Stuart J. Murray (eds.). The Ethics of Care: Moral Knowledge, Communication, and the Art of Caregiving. London and New York: Routledge, 2017. 248 pp., hardcover $\$ 160.00$ (9781472475596); \$54.95 ebook (9781315616162)

Brady, Michelle, ed. Governing Practices Neoliberalism, Governmentality, and the Ethnographic Imaginary. Toronto: University of Toronto Press, 2016. 274 pp., \$29.95 paper (9781487520618)

Brubaker, Rogers. Trans: Gender and Race in an Age of Unsettled Identities. Princeton, N.J. Princeton University Press, 2016. 236 pp., \$24.95 hardcover (9780691172354)

Clemens, Elizabeth J. What is Political Sociology? Cambridge and Malden: Polity, 2016. 166 pp., \$23.99 paper (9780745691619) 
Clift, Rebecca. Conversational Analysis. Cambridge: Cambridge University Press, 2016. 316 pp., \$45.72 paper (9780521157193)

Coles, Roman. Visionary Pragmatism: Radical and Ecological Democracy in Neoliberal Times. Durham, N.C. Duke University Press, 2016. 240 pp., \$23.95 paper (978-0-8223-6064-3)

Crehan, Kate. Gramsci's Common Sense: Inequality and its Narratives. Durham, N.C. Duke University Press, 2016. 222 pp., \$23.95 paper (978-0-8223-6239-5)

Curran, Dean. Risk, Power, and Inequality in the 21st Century. New York: Palgrave Macmillan, 2016. 185 pp., \$100.00 hardcover (9781137495563)

Edelman, Lauren B. Working Law: Courts, Corporations, and Symbolic Civil Rights. Chicago and London: University of Chicago Press, 2016. 349 pp., \$30.00, paper (9780226400761)

Fassin, Didier. Translated by Rachel Gomme. Prison Worlds: An Ethnography of the Carceral Condition. Cambridge and Malden: Polity Press, 2017. 383 pp. \$34.95 paper (9781509507550)

Fenton, Natalie. Digital, Political, Radical. Cambridge and Malden: Polity, 2016. 226 pp., \$29.95 paper (9780745650876)

Fontes, Paulo. Translated by Ned Sublette. Migration and the Making of Industrial Sao Paulo. Durham, N.C.: Duke University Press, 2016. 296 pp., \$25.95 paper (978-0-8223-6134-3)

Genov, Nikoai. Global Trends and Regional Development. London and New York: Routledge, 2016. 335 pp., \$63.25 hardcover (9780415897631)

Gingras, Yves. 2016. Bibliometrics and Research Evaluation: Uses and Abuses. Cambridge, MA: MIT Press. 136 pp., \$26.00 hardcover (9780262035125)

Goldstein, Daniel M. Owners of the Sidewalk: Security and Survival in the Informal City. Durham, N.C. Duke University Press, 2016. 352 pp., \$26.95 paper (978-0-8223-6045-2)

Haraway, Donna J. Staying with the Trouble: Making Kin in the Chthulucene. Durham, N.C.: Duke University Press, 2016. 312 pp., $\$ 26.95$ paper (9780822362241) 
Harries-Jones, Peter. Upside Down Gods: Gregory Bateson's World of Difference. New York: Fordham University Press, 2016. 279 pp., $\$ 35.00$ paper (9780823270354)

Helmreich, William. The Brooklyn Nobody Knows: An Urban Walking Guide. Princeton, N.J. Princeton University Press, 2016. 424 pp., \$24.95 paper (9780691166827)

Hodge Bob. Social Semiotics for a Complex World. Cambridge and Malden: Polity Press, 2017. 258 pp. \$26.95 paper (9780745696218)

Huey, Laurel. Adding Insult to Injury: (Mis)Treating Homeless Women in Our Mental Health System. Denver: Lynne Rienner, 2016. 171 pp., \$59.95 US hardcover (9781626375611)

Karjanen, David J. 2016. The Servant Class City: Urban Revitalization versus the Working Poor in San Diego. Minneapolis: University of Minnesota Press. 312 pages, paper. \$28.00 (9780816697489)

Kenney J. Scott. 2016. Brought to Light: Contemporary Freemasonry, Meaning and Society. Waterloo: Wilfrid Laurier University Press. 320 pp., \$38.99 paper (9781771121941)

Lawrence, Emily Estelle. The Brain's Body: Neuroscience and Corporeal Politics. Durham, N.C. Duke University Press, 2016. 192 pp., \$22.95 paper (978-0-8223-6126-8)

Lee, Doreen. Activist Archives: Youth Culture and the Political Past in Indonesia. Durham, N.C. Duke University Press 2016. 296 pp., \$24.95 paper (978-0-8223-6171-8)

McLean, Paul. Culture in Networks. Cambridge and Malden: Polity Press, 2017. 235 pp., paper, \$27.95 (9780745687179)

Noble, Brian. Articulating Dinosaurs: A Political Anthropology. Toronto: University of Toronto Press, 2016. 491 pp., \$47.95 paper (9781442627055)

Ong, Aihwa. Fungible Life: Experiment in the Asian City of Life. Durham, N.C.: Duke University Press, 2016. 280 pp., \$25.95 paper (97808223-62647)

Parsa, Misagh. Democracy in Iran: Why it Failed and How it Might Succeed. Cambridge, MA: Harvard University Press, 2016. 406 pp., \$45.00 hardcover (978-0674545045) 
Raud, Rein. Meaning in Action: Outline of an Integral Theory of Culture. Hoboken, N.J. Wiley Blackwell, 2016. 193 pp., \$29.95 paper (9781509511259)

Rose, Hilary. Can Neuroscience Change our Minds? Cambridge and Malden: Polity, 2016. 170 pp., \$12.95 paper (9780745689326)

Steinmetz, Kevin F. Hacked: A Radical Approach to Hacker Culture and Crime. New York: New York University Press, 2016. 288 pp., $\$ 28.00$ paper (9781479869718)

Thiele, Leslie Paul. Sustainability: $2^{\text {nd }}$ Edition. Cambridge and Malden: Polity, 2016. 254 pp., \$24.95 paper (9781509511075)

Urry, John. What is the Future? Cambridge and Malden: Polity, 2016. 226 pp., \$19.95 paper (9780745696546)

Weiss, Brad. Real Pigs: Shifting Values in the Field of Local Pork. Durham, N.C.: Duke University Press, 2016. 312 pp., \$29.95 paper (978-0-8223-6157-2)

White, Michael D. and Henry F. Fradella. Stop and Frisk: The Use and Abuse of a Controversial Policing Tactic. New York: New York University Press, 2016. 256 pp., \$30.00 hardcover (9781479835881)

Wiley, Angela. Undoing Monogamy: The Politics of Science and the Possibilities of Biology. Durham, N.C. Duke University Press, 2016. 216 pp., \$23.95 paper (978-0-8223-6159-6) 